\title{
Localization of Magic-F1 Transgene, Involved in Muscular Hypertrophy, during Early Myogenesis
}

\author{
Flavio Ronzoni, ${ }^{1,2}$ Matilde Bongio, ${ }^{1}$ Silvio Conte, ${ }^{1}$ Luigi Vercesi, ${ }^{1}$ \\ Marco Cassano, ${ }^{3}$ Carla Tribioli, ${ }^{4}$ Daniela Galli, ${ }^{1,2}$ Riccardo Bellazzi, ${ }^{2}$ Giovanni Magenes, ${ }^{2}$ \\ Maria Gabriella Cusella De Angelis, ${ }^{1,2}$ and Maurilio Sampaolesi ${ }^{1,2,3,5}$
}

\author{
${ }^{1}$ Human Anatomy Section, University of Pavia, Via Forlanini 8, 27100 Pavia, Italy \\ ${ }^{2}$ Center for Tissue Engineering (CIT), University of Pavia, 27100 Pavia, Italy \\ ${ }^{3}$ Translational Cardiomyology (SCIL), Katholieke Universiteit Leuven, Herestraat 49, 3000 Leuven, Belgium \\ ${ }^{4}$ Institute of Molecular Genetics, CNR, 27100 Pavia, Italy \\ ${ }^{5}$ Stem Cell Research Institute, University Hospital Gasthuisberg, Herestraat 49, 3000 Leuven, Belgium \\ Correspondence should be addressed to Maurilio Sampaolesi, sampa@unipv.it
}

Received 31 May 2011; Revised 14 September 2011; Accepted 19 September 2011

Academic Editor: Aikaterini Kontrogianni-Konstantopoulos

Copyright (๑) 2011 Flavio Ronzoni et al. This is an open access article distributed under the Creative Commons Attribution License, which permits unrestricted use, distribution, and reproduction in any medium, provided the original work is properly cited.

\begin{abstract}
We recently showed that Magic-F1 (Met-activating genetically improved chimeric factor 1), a human recombinant protein derived from hepatocyte growth factor/scatter factor (HGF/SF) induces muscle cell hypertrophy but not progenitor cell proliferation, both in vitro and in vivo. Here, we examined the temporal and spatial expression pattern of Magic-F1 in comparison with Pax3 (paired box gene 3) transcription factor during embryogenesis. Ranging from 9.5 to $17.5 \mathrm{dpc}$ (days post coitum) mouse embryos were analyzed by in situ hybridization using whole mounts during early stages of development (9.5-10.5-11.5 dpc) and cryostat sections for later stages (11.5-13.5-15.5-17.5 dpc). We found that Magic-F1 is expressed in developing organs and tissues of mesenchymal origin, where Pax3 signal appears to be downregulated respect to the wt embryos. These data suggest that Magic-F1 could be responsible of muscular hypertrophy, cooperating with Pax3 signal pathway in skeletal muscle precursor cells.
\end{abstract}

\section{Introduction}

Muscular hypertrophy is controlled by both muscle growth and muscle atrophy. These apparently contrasting biological processes share key molecules triggering active transcriptional programs to induce skeletal muscles atrophy or hypertrophy.

The IGF-1 (insulin-like growth factor-1) pathway affects both hypertrophy and atrophy, increasing protein synthesis and inhibiting the expression of transcription factor FOXO (forkhead box O), respectively. A key molecular player downstream of IGF-1 receptor is Akt (Abelson leukemia kinase) that when phosphorylated activates protein synthesis via mTOR (mammalian target of rapamycin). The two main actors to negatively control the muscle growth are myostatin and atrogin- 1 . Myostatin belongs to the TGF- $\beta$ (transforming growth factor beta) family, and it is expressed and secreted predominantly in skeletal muscle, functioning as negative regulator of muscle growth. Mice, sheep, cattle, and humans that present mutations in myostatin gene show a double-muscling phenotype, characterized by extensive muscular hypertrophy [1-4]. In vitro myostatin is able to positively affect the expression of ubiquitin ligases, involved in muscle atrophy [5]. Interestingly, myostatin treatment blocks the IGF1-AKT pathway, allowing the increased expression of atrogin-1, directly involved in muscle atrophy [6]. Among the muscle growth regulators, hepatocyte growth factor (HGF/SF) [7-9], initially unveiled as the major inducers of hepatogenesis, is involved in muscle stem-cell activation through its tyrosine kinase receptor Met [10-14], containing a Pax3-binding site. Pax3 is an early transcription factor involved in embryonic and adult myogenesis, and it is expressed in the lateral dermomyotome of all somites, where also is present Met [15]. Transgenic animals generated to interfere in HGF-Met signaling show abnormality in several muscles during embryogenesis [16-18]. Moreover, HGF-Met 
pathway is important in muscle regeneration, since, sustains the proliferation of muscle stem cells after their activation [19-22]. However, HGF expression is downregulated during myogenesis in order to allow the satellite cells to exit the cell cycle, avoiding a delay in the regeneration process $[23,24]$.

The production of recombinant proteins allows the great advantage to select a specific biological effect of a given protein able to trigger different biological processes. We recently generated transgenic mice expressing an HGFrelated recombinant protein, named Magic factor-1 (Metactivating genetically improved chimeric factor- 1 or MagicF1) and expressed exclusively in skeletal muscles [25]. This animal model develops muscular hypertrophy with no evident side effects or hyperplasia. However, the expression pattern of the transgene in early embryogenesis is unknown.

The effect of Magic-F1 recombinant protein in skeletal muscle tissue offers biological advantages over HGF. MagicF1 is able to promote myocytes survival and enhance muscle regeneration and a lack of any mitogenic activity could allow a potential safe use of the recombinant protein as therapeutic cytokine for muscle degenerative disorders, promoting muscle regeneration without the potential risk of stimulating uncontrolled proliferation. Because of its selective stimulation of hypertrophy, Magic-F1 is a novel molecule with potential applicative perspective to counteract muscle wasting in muscle diseases such as cachexia or muscular dystrophy.

Here, we evaluate the localization of transgene MagicF1 in comparison with Pax3, the earliest myogenic transcription factor, in early and late embryogenesis using in situ hybridization on whole-mount and cryosections of transgenic and wt mouse embryos.

\section{Materials and Methods}

2.1. Mouse Embryos and Staging. Embryos for in situ hybridization were dissected from CD1 wt (wild-type) female mice mated with homozygous Magic-F1 transgenic male mice (Stem Cell Research Institute, H. S. Raffaele, Milan, Italy). Embryos were generated using timed mating, with the morning vaginal plug designated as E0.5.

2.2. Genotyping of Magic-F1 Embryos. Magic-F1 is a recombinant protein containing two HGF NK2 domains joint by a linker. The exact amino acidic sequence of Magic-F1 corresponds to residues 1-285 of human HGF (Gene Bank no. M73239), a linker with the sequence (GGGGS)3; residues 30-285 of human HGF, and a poly-histidine tag with the sequence DDDKHHHHHH. We generated transgenic mice expressing Magic-F1 construct into a plasmid containing the 1.500-bp (base pair) fragment of the MLC (myosin light chain) promoter, an 840-bp fragment of SV40 poly(A), and a 900-bp fragment from the $3^{\prime}$ end of the MLC1f/3f gene, which acts as an enhancer as previously reported [25].

To determinate the genotypes of the embryos used in this study, the yolk sack was removed from each embryo and was used to prepare genomic DNA (deoxyribonucleic acid), according to a modified protocol using proteinase $\mathrm{K}$ digestion, isopropanol extraction, and ethanol precipitation. Oligonucleotide primers $F W$ (forward) (5'GTGTCAAGGTTCTATTAGGCACTA- $3^{\prime}$ ) and REV (reverse) $\left(5^{\prime}\right.$-GTCCTTTACCAATGATGCAGTTTC- $\left.{ }^{\prime}\right)$, were used to amplify a $331 \mathrm{bp}$ fragment specific to Magic-F1. For each sample, $20 \mathrm{ng}$ of genomic DNA was subjected to a cycle of predenaturation $\left(94^{\circ} \mathrm{C}, 3\right.$ minutes and 30 seconds), then to 30 cycles of amplification consisting of denaturing $\left(94^{\circ} \mathrm{C}\right.$, 15 seconds), annealing $56^{\circ} \mathrm{C}, 30$ seconds) and extension $\left(72^{\circ} \mathrm{C}, 45\right.$ seconds), followed by two additional extensions at $72^{\circ} \mathrm{C}, 7$ minutes). The amplified products were analyzed by agarose gel electrophoresis in TBE (Tris Borate EDTA) 1X. To confirm that the absence of the band of some samples was due to the absence of Magic-F1 gene and not to the absence of DNA, a PCR (polymerase chain reaction) has been performed for GAPDH (glyceraldehyde3-phosphate dehydrogenase) gene, using oligonucleotide primers $F W\left(5^{\prime}\right.$-GGGTGGAGCCAAACGGGT- $\left.3^{\prime}\right)$ and REV (5'-GGAGTTGCTGTTGAAGTCGCA). For each sample, $20 \mathrm{ng}$ of genomic DNA was subjected to a cycle of predenaturation $\left(94^{\circ} \mathrm{C}, 5\right.$ minutes), then to 35 cycles of amplification consisting of denaturing $\left(94^{\circ} \mathrm{C}, 60\right.$ seconds), annealing $\left(60^{\circ} \mathrm{C}, 60\right.$ seconds) and extension $\left(72^{\circ} \mathrm{C}, 60\right.$ seconds $)$, followed by an additional extension at $72^{\circ} \mathrm{C}, 7$ minutes.

2.3. Plasmid and Riboprobe Synthesis. As probes for hybridization experiments, human Magic-F1 cDNA (complementary deoxyribonucleic acid) (1759bp) was amplified using oligonucleotide primers FW $\left(5^{\prime}\right.$ ATGTGGGTGACCAACTCCTG-3 $\left.{ }^{\prime}\right)$ and REV (5'CTAGTGGTGGTGGTGGTGGTG-3'). The amplified products were analyzed by agarose gel electrophoresis in TBE 1X. Magic-F1 bands were excised from the gel, and the Magic-F1 DNA was extracted (QIAquick Gel Extraction Kit, QIAgen). Magic-F1 fragments were subcloned into the pGEM-T Easy Vector System (Promega). Nonradioactive antisense and sense riboprobes were synthesized by in vitro transcription using digoxigenin-UTP following the manufactures instructions (Boehringer Mannheim). MagicF1 antisense and sense probes were synthesized using SP6/ T7 RNA (ribonucleic acid) polymerase linearization at a suitable site: $p G E M-T$ carrying Magic-F1 was digested with BstXI and Magic-F1 antisense probes were synthesized using T7 RNA polymerase; Magic-F1 sense probes were synthesized using SP6 RNA polymerase after digestion with ApaI restriction enzyme. The Pax3 antisense and sense probes were produced by T7 and SP6 RNA polymerase from $p C M V$-sport6.1 (Invitrogen) carrying Pax3 cDNA after proper linearization with EcoRI and BamH1, respectively.

2.4. In Situ Hybridization. Whole-mount in situ hybridization on mouse embryos was performed as described [26]. Briefly, embryos were dissected free of all membranes in phosphate-buffered saline (PBS) and fixed in 4\% paraformaldehyde in PBS for 1-2 h at RT (Room Temperature) with slow rocking speed. After washing twice in PTW (PBS, 0.1\% Tween-20), embryos were washed with $50 \% \mathrm{MeOH} / \mathrm{PTW}$ and $100 \% \mathrm{MeOH}$ then stored in $100 \%$ $\mathrm{MeOH}$ at $-20^{\circ} \mathrm{C}$ for less than a month. For hybridization, 


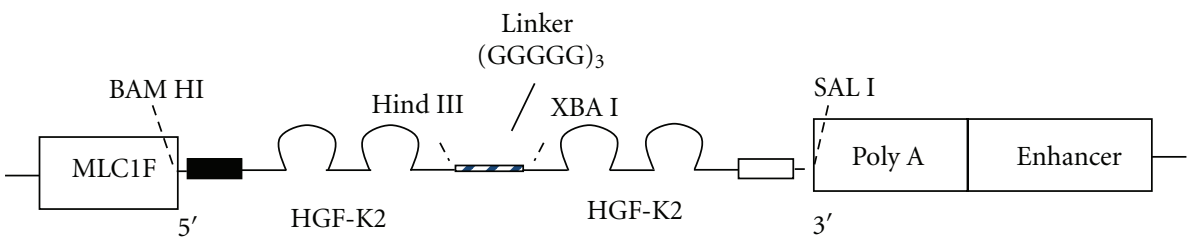

(a)

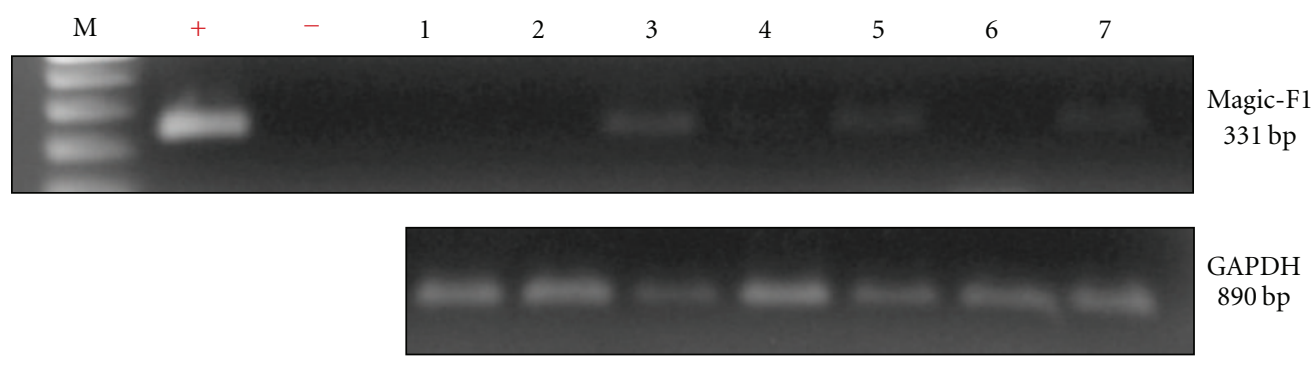

(b)

FIgure 1: Magic-F1 transgenic mice. (a) Schematic representation of transgene. (b) Genotyping of 13.5 dpc mouse embryos derived by hemizygous-matched mice; +, - positive and negative control, respectively.
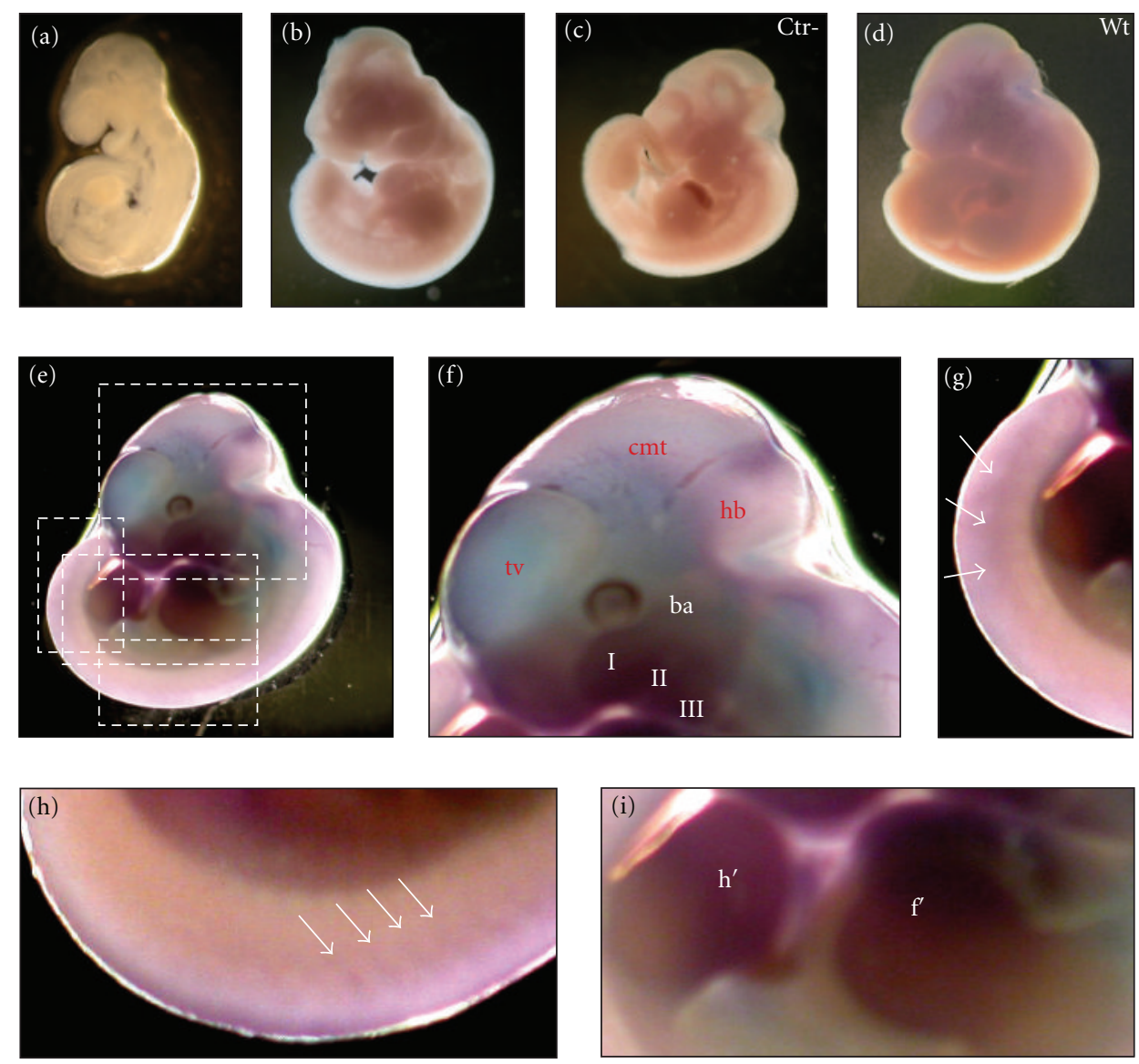

FIgURE 2: Expression of Magic-F1 in whole mount embryos. Lateral view of whole-mount in situ hybridization with digoxigenin labeled antisense Magic-F1 (a, b, d, e, f, g, h, and i) and sense Magic-F1 (c) cRNA probes as negative control (ctr-). Specific hybrids are visualized as a purple precipitate in all panels except in (a), $9.5 \mathrm{dpc}$ and (b) $10.5 \mathrm{dpc}$. (e) Specific Magic-F1 transcripts are detected (f) in the mesodermal cells of the jaw and hyoid bone; in $\mathrm{f}$, tv: telencephalic vesicles, cmt: mesenchymal cephalic tissue, hb: hindbrain, and ba: branchial arches where muscles are localized as well as around the eyes; a faint expression is also revealed in tail ( $g$ ) and dorsal (h) somites, while a strong signal was selected in somites of fore ( $\left.f^{\prime}\right)$ and hind $\left(h^{\prime}\right)$ limb buds (i). In embryos hybridized with sense probe (c) background staining has not been detected as well as on $11.5 \mathrm{dpc}$ wild type embryo (wt) hybridized with antisense probes (d). 

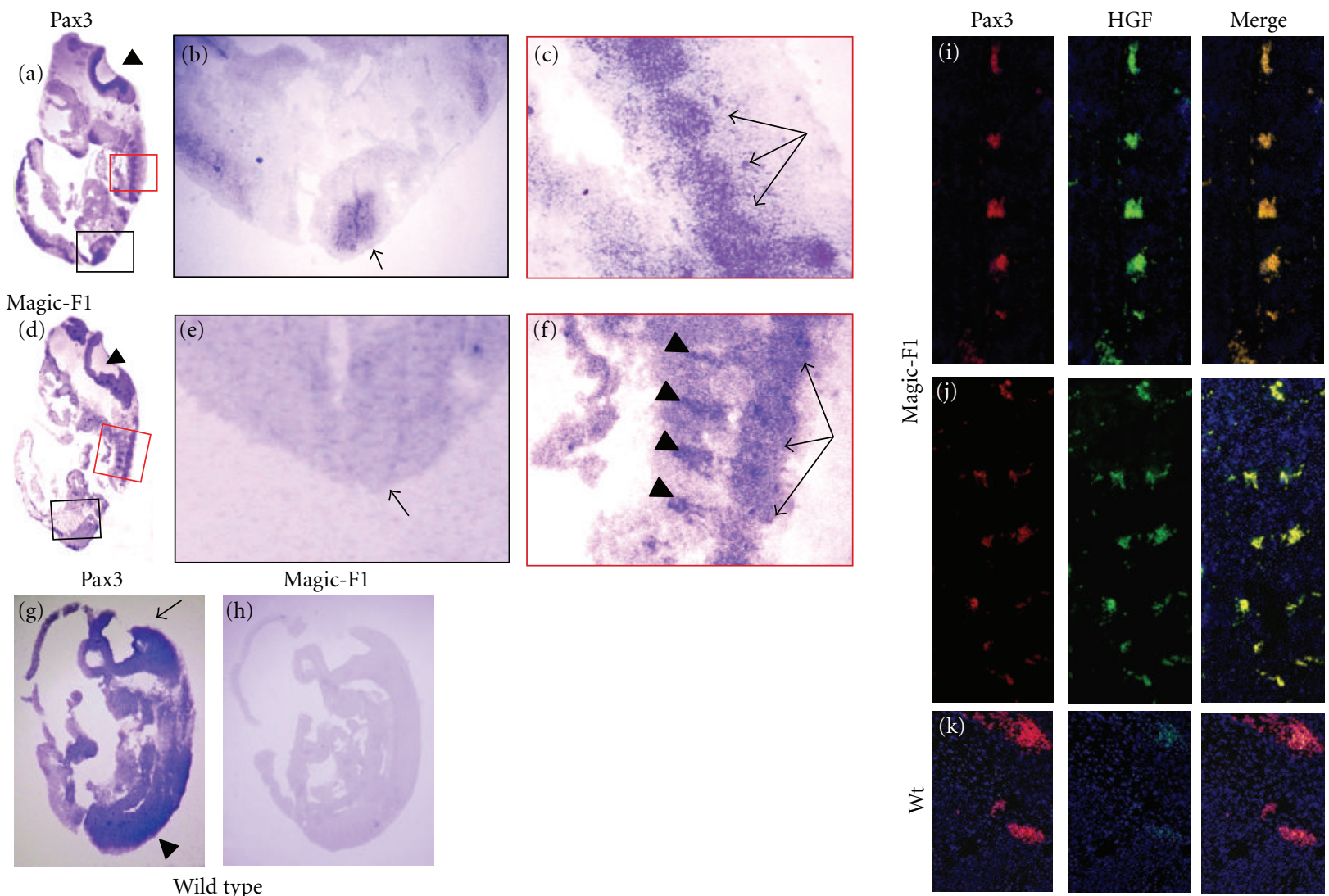

Wild type
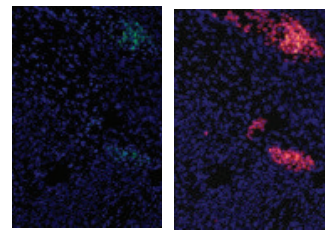

Figure 3: Transcription expression profile of $\operatorname{Pax3}$ (a-c) and Magic-F1 (d-f) on $11.5 \mathrm{dpc}$ mouse embryos of hemizygous Magic-F1 (a-f) and wt (g, h) mice by in situ hybridization. In the sagittal section of transgenic embryo, Pax3 riboprobes reveal a strong signal at the level of hindbrain (arrowhead in a), neuroepithelium of neural tube (arrow in b), and dorsal somites (c); sagittal section of $11.5 \mathrm{dpc}$ embryo hybridized by Magic-F1 riboprobes (d) shows a similar pattern of Pax3 although no expression was detected at the level of neuroepithelium of neural tube (arrow in e); specific transcripts are observed in the cervical dorsal (posterior) root ganglion (arrows in c and $\mathrm{f}$ ) and somites (arrowheads in f). In $11.5 \mathrm{dpc}$ wt embryo hybridized with Pax3 riboprobes (g), specific transcripts are detected mostly in the cerebellar primordium (cerebellar rudiment derived from dorsal part of the alar lamina of the Metencephalon) (arrow) and somites in lumbar region (arrowhead in $\mathrm{g}$ ), whereas no signal for Magic-F1 has been detected (h). Immunofluorescence analysis confirmed the presence of recombinant protein at the level of thoracic (i) and lumbar (j) somites in the transgenic embryos, whereas the signal was faint in the wt embryos (k), probably referred only to the HGF expression at this stage.

embryos were incubated horizontally at $65^{\circ} \mathrm{C}$ overnight in hybridization mix $(50 \%$ deionized formamide, $1.3 \mathrm{xSSC} \mathrm{pH}$ $5,5 \mathrm{mM}$ EDTA pH $8,50 \mu \mathrm{g} / \mathrm{mL}$ Yeast RNA, $0.2 \%$ Tween20, $0.5 \%$ CHAPS, $100 \mu \mathrm{g} / \mathrm{mL}$ Heparin, $\mathrm{ddH}_{2} \mathrm{O}$ ) with $1 \mu \mathrm{g} / \mathrm{mL}$ digoxigenin-labeled RNA probes. After in situ hybridization, the embryos were washed in MABT buffer $(100 \mathrm{mM}$ maleic acid (Sigma), $150 \mathrm{mM} \mathrm{NaCl}, 0.1 \%$ Tween-20, $\mathrm{pH} 7.5$ ) and NTMT buffer $(100 \mathrm{mM} \mathrm{NaCl}, 100 \mathrm{mM}$ Tris- $\mathrm{HCl} \mathrm{pH} 9.5$, $50 \mathrm{mM} \mathrm{MgCl} 2,0.1 \%$ Tween-20) and incubate with staining solution $(4.5 \mu \mathrm{g} / \mathrm{m}$ NBT and $3.5 \mu \mathrm{g} / \mathrm{mg}$ BCIP). When the developed color reached the desired extent, embryos were washed twice with PTW and refixed in $4 \% \mathrm{HCHO} / 0.1 \%$ glutaraldehyde/PTW for $2 \mathrm{~h}$ at $\mathrm{RT}$ or $4^{\circ} \mathrm{C}$ overnight.

In situ hybridization on mouse cryostat sections was performed according to Sally Dunwoodie, NIMR. Briefly, the sections were fixed $4 \%$ paraformaldehyde in PBS, digested with proteinase $\mathrm{K}$ and postfixed. Sections were prehybridized in hybridization solution without probe $(50 \%$ deionized formamide, 10x salt, $250 \mu \mathrm{g} / \mathrm{mL}$ Yeast RNA, 5x Denhardt's, $50 \mu \mathrm{g} / \mathrm{mL}$ Heparin, $0.1 \%$ Tween, $\mathrm{ddH}_{2} \mathrm{O}$ ) in a humid environment at $67^{\circ} \mathrm{C}$ for $2 \mathrm{~h}$. After incubation, the prehybridization buffer was removed and replaced with hybridization buffer containing everything in the prehybridization buffer plus $0.1-1 \mu \mathrm{g} / \mathrm{mL}$ labeled cRNA (complementary ribonucleic acid) riboprobe, denatured for $5 \mathrm{~min}$ at $80^{\circ} \mathrm{C}$. A coverslip was placed over the hybridized area and the slides were then placed in a moist, closed plastic box and hybridized overnight at $67^{\circ} \mathrm{C}$ h. Following hybridization, the coverslips were washed off by dipping into $50 \%$ formamide, 1xSSC prewarmed to $67^{\circ} \mathrm{C}$. The tissue was subjected to stringent washing at $67^{\circ} \mathrm{C}$ in $50 \%$ formamide, $1 \mathrm{xSSC}$ twice for $30 \mathrm{~min}$, followed by two washes in MABT 1X at RT, for $30 \mathrm{~min}$ each. Slides were exposed to BMpurple (Roche) for $2 \mathrm{~h}$. Slides were fixed in PFA $4 \%$ and washed in PBS, three times for 5 min. Hybridization signals were observed and photographed using a Nikon microscope. As a negative 


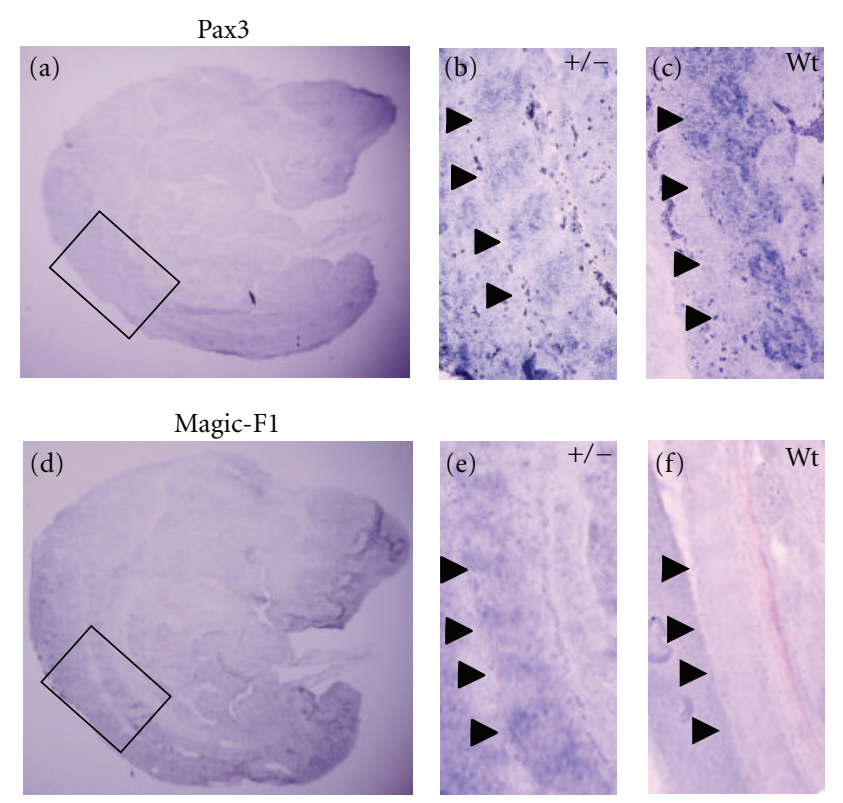

FIgURE 4: Expression of Pax3 and Magic-F1 in 13.5 dpc mouse embryos. (a) Sagittal section of 13.5 dpc mouse hybridized by Pax3 riboprobes. A weak signal of Pax3 transcripts have been detected in Magic-F1 transgenic embryos (+/-) at the level of somites in thoracic (b) and lumbosacral region; in the wild-type age-matched embryo (wt) the signal appeared slightly stronger (c). A faint signal was detected at the same stage in transgenic embryos hybridized by Magic-F1 antisense riboprobes (d); mainly, the transgenic expression was localized at the level of somites as shown at higher magnification in (e). No signal was detected in wild type embryos (wt) by Magic-F1 antisense riboprobes (f). Arrowheads show somites.

control, specimens were incubated with hybridization buffer containing digoxigenin labeled riboprobes corresponding to the sense sequence of Magic-F1.

2.5. Immunochemistry. Cryosections placed in a humid, closed plastic box were fixed for $10 \mathrm{~min}$ in $4 \%$ paraformaldehyde in PBS, permeabilized in $0.2 \%$ Triton and incubated, first, with a blocking buffer ( $2 \%$ donkey serum) containing $1 \%$ blocking solution in PBS for $30 \mathrm{~min}$ at RT and, then, a second blocking buffer $(0.5 \%$ mouse serum, $0.5 \%$ goat serum) containing 1\% Blocking Solution (Candorbioscience $\mathrm{GmbH}$ ) in PBS for $30 \mathrm{~min}$ at RT, followed by incubation with primary antibodies (goat polyclonal antibody anti-HGF, $1: 100$ and Mouse monoclonal antibody anti-Pax3) diluted in 2\% BSA (bovine serum albumine) in PBS overnight at $4^{\circ} \mathrm{C}$. Sections were rinsed three times in PBS followed by a $2 \mathrm{~h}$ incubation with fluorescein-conjugated anti-mouse and anti-goat antibodies diluted 1/1500. Slides were stained with Hoechst dye and mounted in FluorSave. Stained cryosections were observed on an upright microscope Nikon Vico TE-2000 (Nikon, Japan).

\section{Results and Discussion}

3.1. PCR Analysis. PCR analysis of Magic-F1 showed transgene expression in all the embryonic developmental stages analyzed and an example at stage $13.5 \mathrm{dpc}$ is reported in Figure 1(b). As expected, no signal was detected in the wildtype embryos due to the high specificity of the primers able to discriminate between HGF and the recombinant protein Magic-F1.
3.2. Whole-Mount In Situ Hybridization. Whole-mount in situ hybridization was performed to detect Magic-F1 and Pax3 mRNA (messenger ribonucleic acid) in embryos at early stages of development $(9.5,10.5$ and $11.5 \mathrm{dpc})$.

Magic-F1 expression was detected in bone cartilage primordia, dorsal somites, in tail and limb buds, where Pax3 signal appears to be downregulated respect to the wt embryos. At $9.5 \mathrm{dpc}$ (30 somite stage) and $10.5 \mathrm{dpc}$ (40 somite stage) (Figures 2(a) and 2(b)), in situ hybridization analysis with digoxigenin- (DIG-) labeled antisense probes showed no expression of Magic-F1 transcript. Magic-F1 transcripts (Figure 2(e)) have been detected from stage of $11.5 \mathrm{dpc}$ (58 somite stage) in developing organs and tissues of mesenchymal origin. Specifically, positive signal was observed in mesodermal cells of the jaw, hyoid bone and in pharyngeal (or brachial) arches from which branchiomeric muscles are formed. This expression profile confirmed the muscle specificity of the MLC1F (myosin light chain type $1 \mathrm{~F}$ ) promoter, regulating Magic-F1 transcription. Furthermore, specific hybrids were also detected around the eyes at the level of the choroid coat and the sclera, both of mesenchymal origin, on the ventral and dorsal side of limb buds (Figure 2(d)), in the dorsal side of some rostral somites (Figure 2(h)), and in the tail bud (Figure 2(g)). No signal was observed in the embryos hybridized with the sense riboprobe (Figure 2(i)). The somites begin to form at the $7.75-8.0 \mathrm{dpc}$, and, after condensation, they begin to differentiate into three compartments: the sclerotome, the dermatome, and myotome. At $11.5 \mathrm{dpc}$ (58 somite stage), Magic-F1 transcripts have been detected in all three compartments (sclerotome, dermatome, 

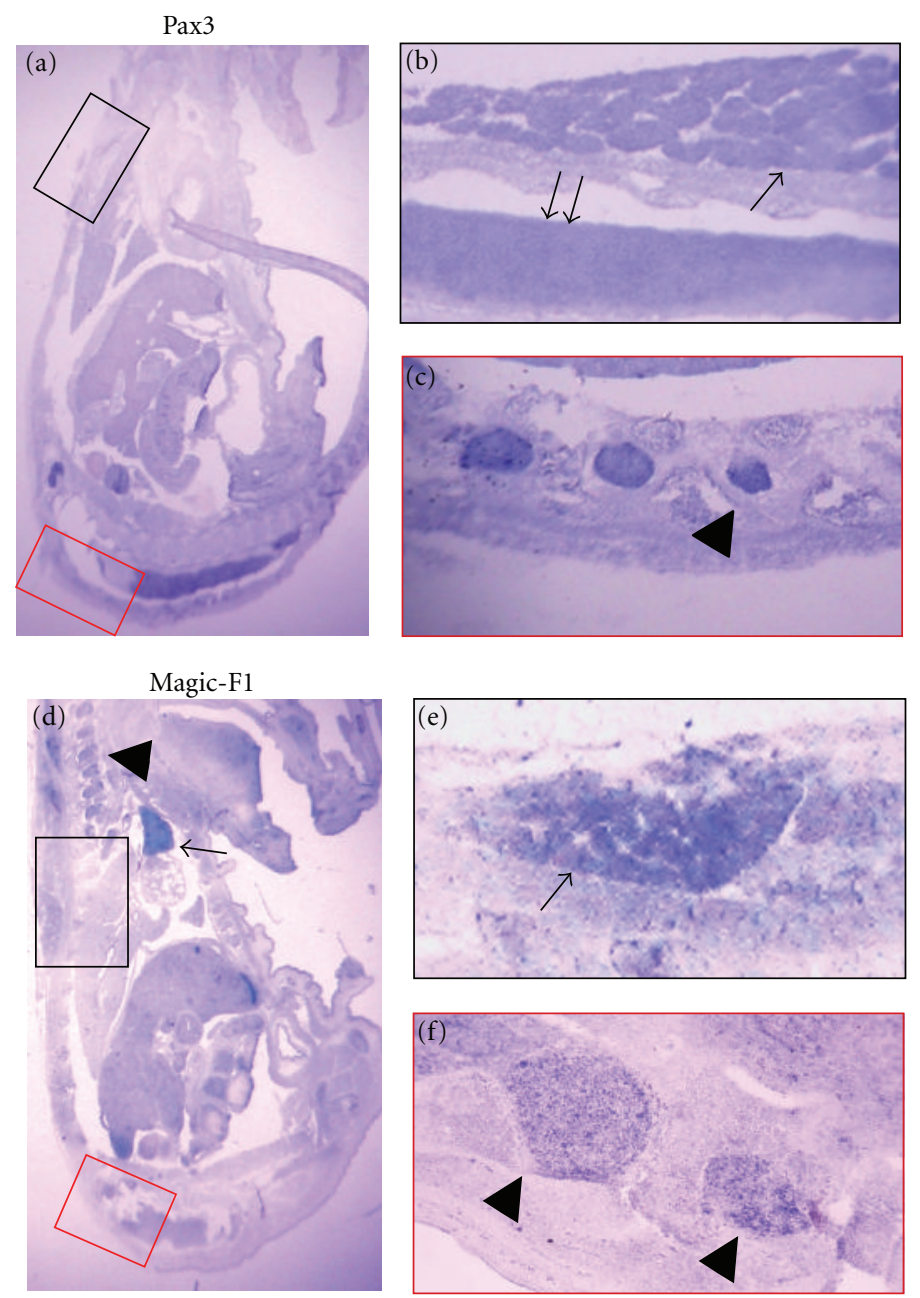

Figure 5: Expression of Pax3 and Magic-F1 at $15.5 \mathrm{dpc}$. Sagittal section of $15.5 \mathrm{dpc}$ mouse hybridized with digoxigenin-labeled antisense Pax3 riboprobes (a); specific Pax3 transcripts are localized in cartilage primordium of tail vertebral body, cutaneous muscles (arrow) of thorax and trunk regions and in mid-cervical region of spinal cord (double arrow) as shown in (b); expression was also localized in cartilage primordium (arrowhead) of dorsal part of shaft region (c); (d) sagittal section of $15.5 \mathrm{dpc}$ mouse hybridized with Magic-F1 cRNA probes and signal is observed in cartilage primordium of anterior arch of cervical vertebra (arrowheads) and right lobe of thymus gland (arrow); specific Magic-F1 transcripts are also localized in cutaneous muscles (arrow) of thorax and trunk regions (e); (f) higher magnification cartilage primordium of dorsal part of shaft region of ribs.

and myotome) originating from somites. No signal was detected in wt embryos at the same stage.

3.3. In Situ Hybridization on Cryostat Sections. In situ hybridization on $10 \mu \mathrm{m}$-cryostat sections was performed to localize Magic-F1 and Pax3 transcripts in embryos at later stages of development (11.5-13.5-15.5-17.5 dpc), since the large size of the samples did not allow a full penetration of the probes.

At $11.5 \mathrm{dpc}$, transgenic mouse embryos showed Pax3 transcripts expression at the level of hindbrain (Figure 3(a)), neuroepithelium of neural tube (Figure 3(b)), and dorsal somites (Figure 3(c)). Magic-F1 riboprobes showed a similar expression pattern (Figure 3(d)) reported for Pax3 although the signal was no detected at the level of neuroepithelium of neural tube in embryos at the same stage (Figure 3(e)). Specific transcripts were also observed in the cervical dorsal (posterior) root ganglion (Figures 3(c) and 3(f)) and somites (Figure 3(f)). In addition, at this stage, Pax3 signal can be observed in wt embryos mainly in the cerebellar primordium and somites in lumbar region (Figure 3(f)), whereas no signal for Magic-F1 has been detected (Figure 3(g)).

3.4. Localization of Pax3 and Magi-F1 Proteins and Transcripts. Immunofluorescence analysis was performed to localize the presence of recombinant protein. In transgenic embryos at $11.5 \mathrm{dpc}$, MAGIC-F1 was mainly detected at the level of thoracic (Figure 3(i)) and lumbar (Figure 3(j)) somites, whereas a faint signal was detected in wt embryos (Figure $3(\mathrm{k})$ ), probably due to the interference with HGF localization in the same area. At $13.5 \mathrm{dpc}$, transgenic embryos showed a weak signal of Pax3 at the level of somites in thoracic (Figure 4(a)) and lumbosacral region (Figure 4(b)), whereas in the wild-type embryo, the signal appeared slightly 

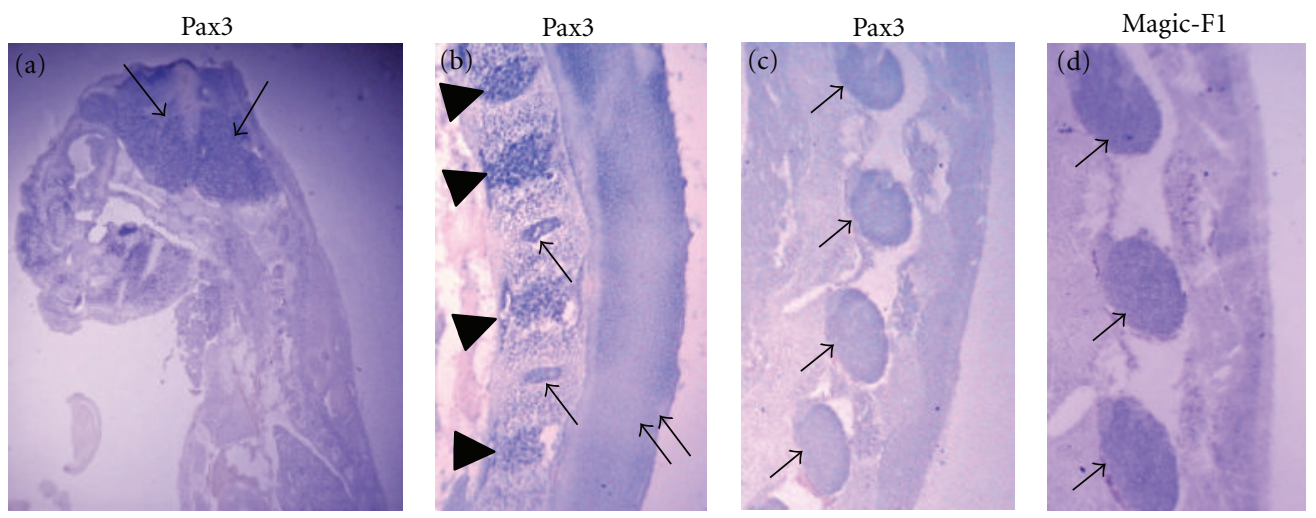

Figure 6: Expression of Pax3 and Magic-F1 at 17.5 dpc. Specific Pax3 transcripts are localized on sagittal sections of 17.5 dpc at the level of the head (a), in the nucleus pulposus (b) of lumbar intervertebral disc (arrows) of the trunk, and in cartilage primordium (arrowheads) and wall of spinal cord in midlumbar region (double arrow) as shown in (b) and in cartilage primordium of dorsal part of ribs (c). (d) Magic-F1 signal was observed at the level of cartilage primordium (arrows) of vertebrae.

stronger (Figure 4(c)). A weak signal have been detected in transgenic embryos hybridized by Magic-F1 antisense riboprobes (Figure 4(d)), where Magic-F1 was mainly expressed at the level of somites (Figure $4(\mathrm{e})$ ), whereas no signal was detected in wild-type embryos (Figure 4(f)). Specific Pax3 transcripts can be detected at later stage $(15.5 \mathrm{dpc})$ (Figure 5(a)) in cartilage primordium of tail vertebral body, cutaneous muscles of thorax and trunk regions, and in midcervical region of spinal cord (Figure 5(b)). In addition, at this stage, Pax3 expression demarcated also cartilage primordium of dorsal part of shaft region (Figure 5(c)). In sagittal section of $15.5 \mathrm{dpc}$ embryo hybridized with MagicF1 cRNA probes a strong signal was detected in cartilage primordium of anterior arch of cervical vertebra and right lobe of thymus gland (Figure 5(d)). Consisted with this, Magic-F1 resulted to be also expressed in cutaneous muscles of thorax and trunk regions (Figure 5(e)) and in primordium of dorsal part of shaft region of ribs (Figure 5(f)). From $17.5 \mathrm{dpc}$ sagittal sections at the level of the head (Figure 6(a)), Pax3 signal was detected in the trunk nucleus pulposus in central part of lumbar intervertebral disc (Figure 6(b)) and in cartilage primordium of dorsal part of ribs (Figure 6(c)). At this stage, Magic-F1 expression was observed at the level of cartilage primordium of vertebrae (Figure 6(d)). These data suggest a role of this factor in muscle development possibly triggering the premature downregulation of Pax3 signal pathway in skeletal muscle precursor cells.

\section{Conclusion}

Taken together, our data show that Magic-F1 is localized in specific expression pattern in the developing muscular tissues. This could be relevant with the muscle phenotype previously observed in the transgenic animal model. The recombinant protein can be considered as a novel member of Met signaling, since it has been shown to interact with, and thus interfering with, cell migration and myogenesis. It is noteworthy that Magic-F1 expression pattern is overlapping with Pax3, however, limited only in developing muscular tissue, where exerts its myogenic potential. In fact, Pax3 is able to activate Myf5 (Myogenic factor 5) myogenic master gene [25], leading to the formation of skeletal muscle. In addition, Pax3 orchestrates FGF (fibroblast growth factor) cascade [27], targeting directly Fgfr4 (fibroblast growth factor receptor 4) and Sprouty1 known to inhibit FGF pathway. Magic-F1 may interfere with the balance between stem cell self-renewal and cell differentiation in developing muscles, mainly operated by Pax3 and Pax7 (paired box gene 7) [28]. It is unlikely that it is directly involved in stem-cell renewal; however, competing with HGF, the natural Met ligand could be move the balance towards muscle differentiation.

Further studies are necessary to elucidate Magic-F1 specific role in cell specification and differentiation during embryogenesis.

\section{Abbreviations}

$\begin{array}{ll}\text { Akt: } & \text { Abelson leukemia kinase } \\ \text { ba: } & \text { Branchial arches } \\ \text { bp: } & \text { Base pair } \\ \text { BSA: } & \text { Bovine Serum Albumine } \\ \text { cmt: } & \text { Mesenchymal cephalic tissue } \\ \text { dpc: } & \text { Days post coitum } \\ \text { DNA: } & \text { Deoxyribonucleic acid } \\ \text { cDNA: } & \text { Complementary deoxyribonucleic acid } \\ \text { FGF: } & \text { Basic fibroblast growth factor } \\ \text { Fgfr4: } & \text { Fibroblast growth factor receptor } 4 \\ \text { FOXO: } & \text { Forkhead box O protein } \\ \text { FW: } & \text { Forward } \\ \text { GAPDH: } & \text { Glyceraldehyde-3-phosphate dehydrogenase } \\ \text { hb: } & \text { Hindbrain } \\ \text { HGF: } & \text { Hepatocyte growth factor } \\ \text { MLC1F: } & \text { Myosin light chain type 1F } \\ \text { mTOR: } & \text { Mammalian target of rapamycin } \\ \text { Myf5: } & \text { Myogenic factor } 5 \\ \text { Pax3: } & \text { Paired box gene } 3 \\ \text { Pax7: } & \text { Paired box gene } 7 \\ \text { PCR: } & \text { Polymerase chain reaction } \\ & \end{array}$


REV: Reverse

RNA: Ribonucleic acid

cRNA: Complementary ribonucleic acid

mRNA: Messenger ribonucleic acid

RT: Room temperature

TBE: Tris borate EDTA

TGF- $\beta$ : Transforming growth factor beta

tv: Telencephalic vesicles

wt: Wild type

WB: Western blot.

\section{Acknowledgments}

This work is supported in part by FWO Odysseus no. G.0907.08, Wicka Funds no. zkb8720, Italian Ministry of University and Scientific Research (Grant no. 2005067555_003), CARIPLO Rif. 2008.2005, and the Italian Research Programme no. PRIN2008RFNT8T_003. Flavio Ronzoni and Matilde Bongio contributed equally to this work.

\section{References}

[1] A. Clop, F. Marcq, H. Takeda et al., "A mutation creating a potential illegitimate microRNA target site in the myostatin gene affects muscularity in sheep," Nature Genetics, vol. 38, no. 7, pp. 813-818, 2006.

[2] S. J. Lee and A. C. McPherron, "Regulation of myostatin activity and muscle growth," Proceedings of the National Academy of Sciences of the United States of America, vol. 98, no. 16, pp. 9306-9311, 2001.

[3] A. C. McPherron and S. J. Lee, "Double muscling in cattle due to mutations in the myostatin gene," Proceedings of the National Academy of Sciences of the United States of America, vol. 94, no. 23, pp. 12457-12461, 1997.

[4] M. Schuelke, K. R. Wagner, L. E. Stolz et al., "Myostatin mutation associated with gross muscle hypertrophy in a child," The New England Journal of Medicine, vol. 350, no. 26, pp. 2682-2688, 2004.

[5] C. McFarlane, E. Plummer, M. Thomas et al., "Myostatin induces cachexia by activating the ubiquitin proteolytic system through an NF- $\kappa \mathrm{B}$-independent, FoxO1-dependent mechanism," Journal of Cellular Physiology, vol. 209, no. 2, pp. 501514, 2006.

[6] D. L. Allen and T. G. Unterman, "Regulation of myostatin expression and myoblast differentiation by FoxO and SMAD transcription factors," American Journal of Physiology, vol. 292, no. 1, pp. C188-C199, 2007.

[7] L. Trusolino and P. M. Comoglio, "Scatter-factor and semaphorin receptors: cell signalling for invasive growth," Nature Reviews Cancer, vol. 2, no. 4, pp. 289-300, 2002.

[8] L. Tamagnone and P. M. Comoglio, "Control of invasive growth by hepatocyte growth factor (HGF) and related scatter factors," Cytokine and Growth Factor Reviews, vol. 8, no. 2, pp. 129-142, 1997.

[9] R. Zarnegar and G. K. Michalopoulos, "The many faces of hepatocyte growth factor: from hepatopoiesis to hematopoiesis," The Journal of Cell Biology, vol. 129, no. 5, pp. 1177-1180, 1995.

[10] A. S. Woolf, M. Kolatsi-Joannou, P. Hardman et al., "Roles of hepatocyte growth factor/scatter factor and the met receptor in the early development of the metanephros," The Journal of Cell Biology, vol. 128, no. 1-2, pp. 171-184, 1995.

[11] H. Takayama, W. J. La Rochelle, M. Anver, D. E. Bockman, and G. Merlino, "Scatter factor/hepatocyte growth factor as a regulator of skeletal muscle and neural crest development," Proceedings of the National Academy of Sciences of the United States of America, vol. 93, no. 12, pp. 5866-5871, 1996.

[12] E. Andermarcher, M. A. Surani, and E. Gherardi, "Coexpression of the HGF/SF and c-met genes during early mouse embryogenesis precedes reciprocal expression in adjacent tissues during organogenesis," Developmental Genetics, vol. 18, no. 3, pp. 254-266, 1996.

[13] F. Maina, M. C. Hilton, C. Ponzetto, A. M. Davies, and R. Klein, "Met receptor signaling is required for sensory nerve development and HGF promotes axonal growth and survival of sensory neurons," Genes \& Development, vol. 11, no. 24, pp. 3341-3350, 1997.

[14] L. Kos, A. Aronzon, H. Takayama et al., "Hepatocyte growth factor/scatter factor-MET signaling in neural crest-derived melanocyte development," Pigment Cell Research, vol. 12, no. 1, pp. 13-21, 1999.

[15] S. Dietrich, F. Abou-Rebyeh, H. Brohmann et al., "The role of SF/HGF and c-Met in the development of skeletal muscle," Development, vol. 126, no. 8, pp. 1621-1629, 1999.

[16] C. Schmidt, F. Bladt, S. Goedecke et al., "Scatter factor/hepatocyte growth factor is essential for liver development," Nature, vol. 373, no. 6516, pp. 699-702, 1995.

[17] Y. Uehara, O. Minowa, C. Mori et al., "Placental defect and embryonic lethality in mice lacking hepatocyte growth factor/scatter factor," Nature, vol. 373, no. 6516, pp. 702-705, 1995.

[18] F. Bladt, D. Riethmacher, S. Isenmann, A. Aguzzi, and C. Birchmeier, "Essential role for the c-met receptor in the migration of myogenic precursor cells into the limb bud," Nature, vol. 376, no. 6543, pp. 768-771, 1995.

[19] S. M. Sheehan, R. Tatsumi, C. J. Temm-Grove, and R. E. Allen, "HGF is an autocrine growth factor for skeletal muscle satellite cells in vitro," Muscle and Nerve, vol. 23, no. 2, pp. 239-245, 2000.

[20] K. J. Miller, D. Thaloor, S. Matteson, and G. K. Pavlath, "Hepatocyte growth factor affects satellite cell activation and differentiation in regenerating skeletal muscle," American Journal of Physiology, vol. 278, no. 1, pp. C174-C181, 2000.

[21] R. Tatsumi, J. E. Anderson, C. J. Nevoret, O. Halevy, and R. E. Allen, "HGF/SF is present in normal adult skeletal muscle and is capable of activating satellite cells," Developmental Biology, vol. 194, no. 1, pp. 114-128, 1998.

[22] Y. Leshem, D. B. Spicer, R. Gal-Levi, and O. Halevy, "Hepatocyte growth factor (HGF) inhibits skeletal muscle cell differentiation: a role for the bHLH protein Twist and the cdk inhibitor p27," Journal of Cellular Physiology, vol. 184, no. 1, pp. 101-109, 2000.

[23] S. Anastasi, S. Giordano, O. Sthandier et al., "A natural hepatocyte growth factor/scatter factor autocrine loop in myoblast cells and the effect of the constitutive met kinase activation on myogenic differentiation," The Journal of Cell Biology, vol. 137, no. 5, pp. 1057-1068, 1997.

[24] R. Gal-Levi, Y. Leshem, S. Aoki, T. Nakamura, and O. Halevy, "Hepatocyte growth factor plays a dual role in regulating skeletal muscle satellite cell proliferation and differentiation," Biochimica et Biophysica Acta, vol. 1402, no. 1, pp. 39-51, 1998.

[25] M. Cassano, S. Biressi, A. Finan et al., "Magic-factor 1, a partial agonist of Met, induces muscle hypertrophy by protecting 
myogenic progenitors from apoptosis," Plos One, vol. 3, no. 9, Article ID e3223, 2008.

[26] D. Henrique, J. Adam, A. Myat et al., "Expression of a Delta homologuein prospective neurons in the chick," Nature, vol. 375, no. 6534, pp. 787-790, 1995.

[27] T. Sato, D. Rocancourt, L. Marques, S. Thorsteinsdóttir, and M. Buckingham, "A Pax3/Dmrt2/Myf5 regulatory cascade functions at the onset of myogenesis," Plos Genetics, vol. 6, no. 4, Article ID e1000897, 2010.

[28] M. Lagha, J. D. Kormish, D. Rocancourt et al., "Pax3 regulation of FGF signaling affects the progression of embryonic progenitor cells into the myogenic program," Genes \& Development, vol. 22, no. 13, pp. 1828-1837, 2008. 

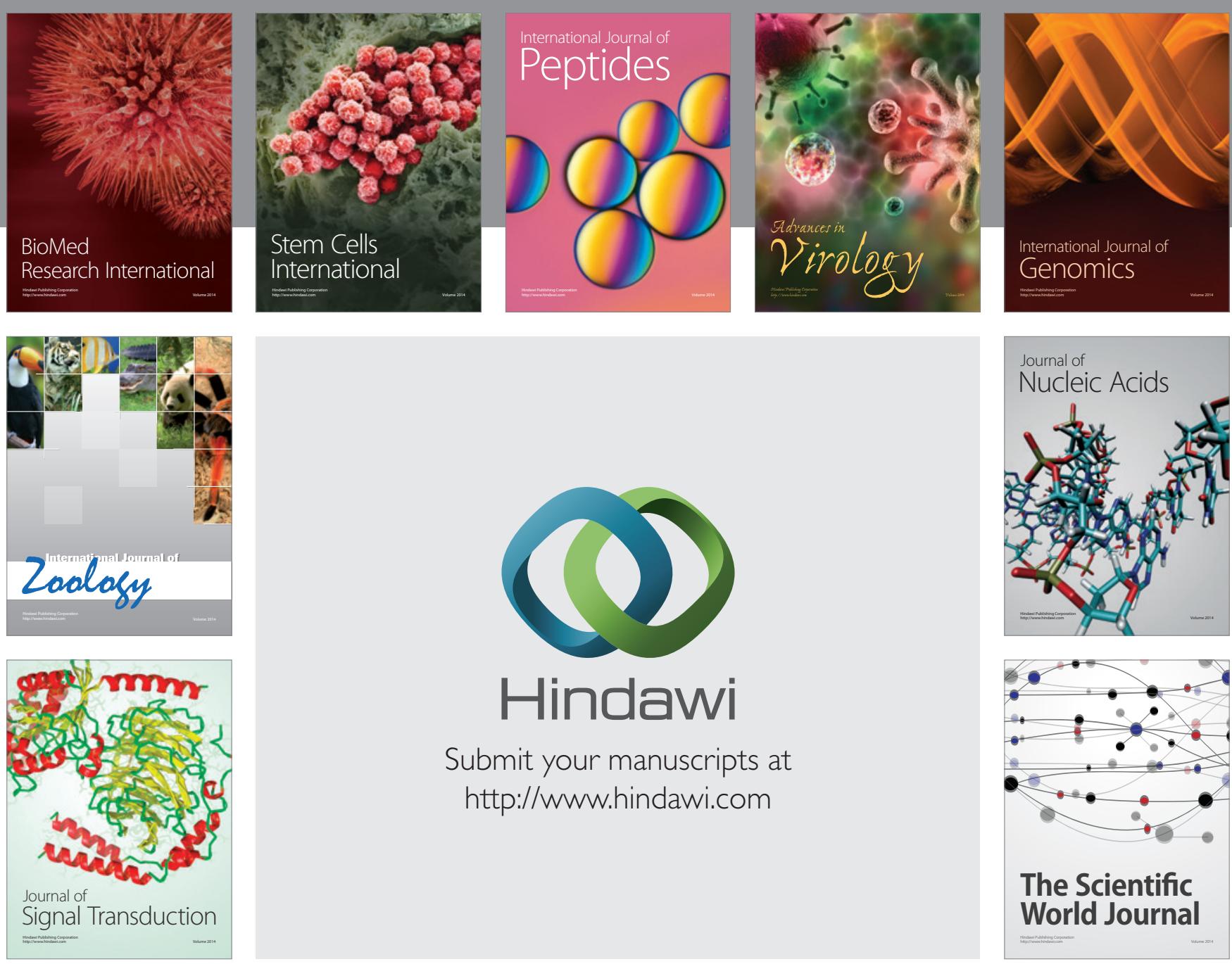

Submit your manuscripts at

http://www.hindawi.com
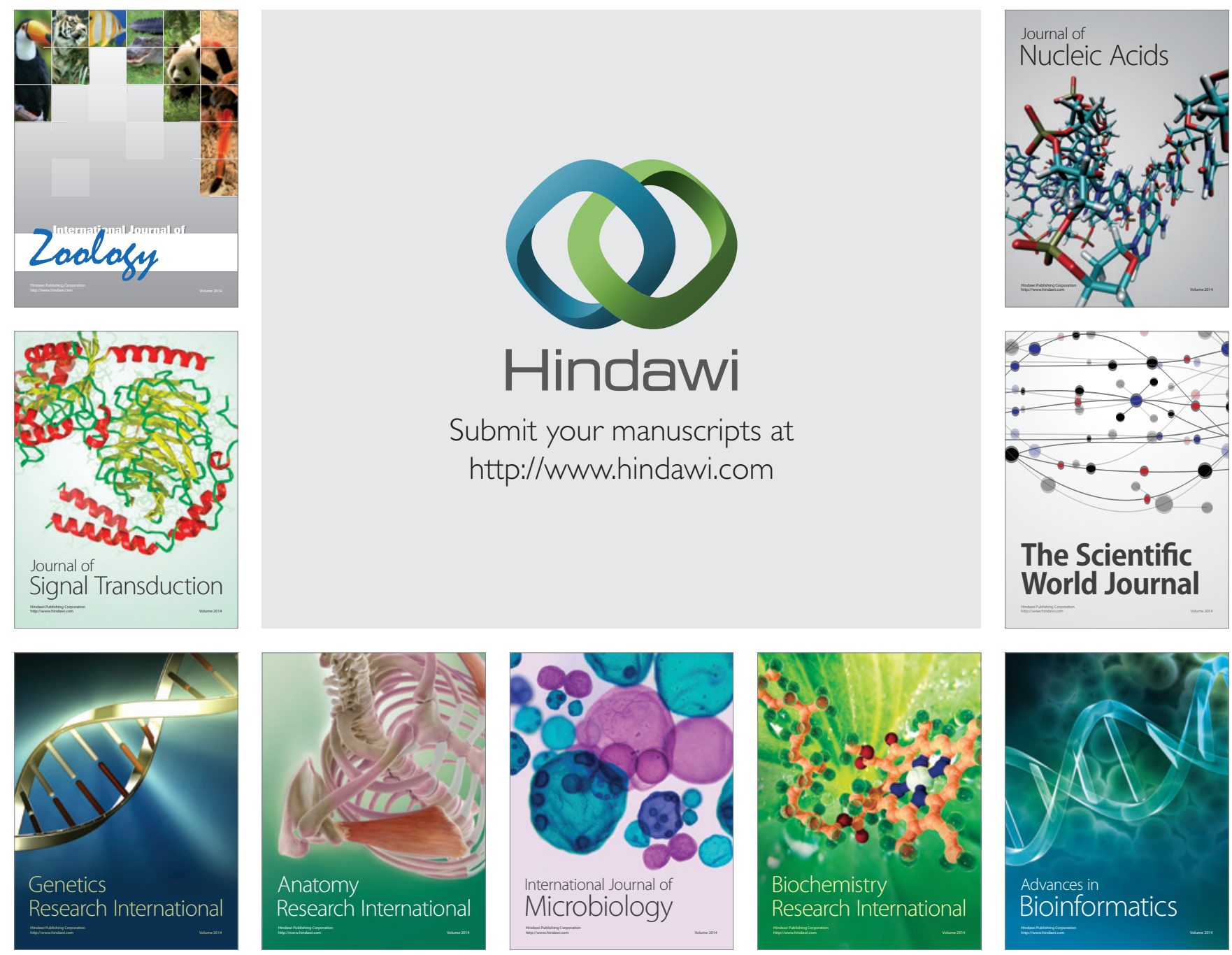

The Scientific World Journal
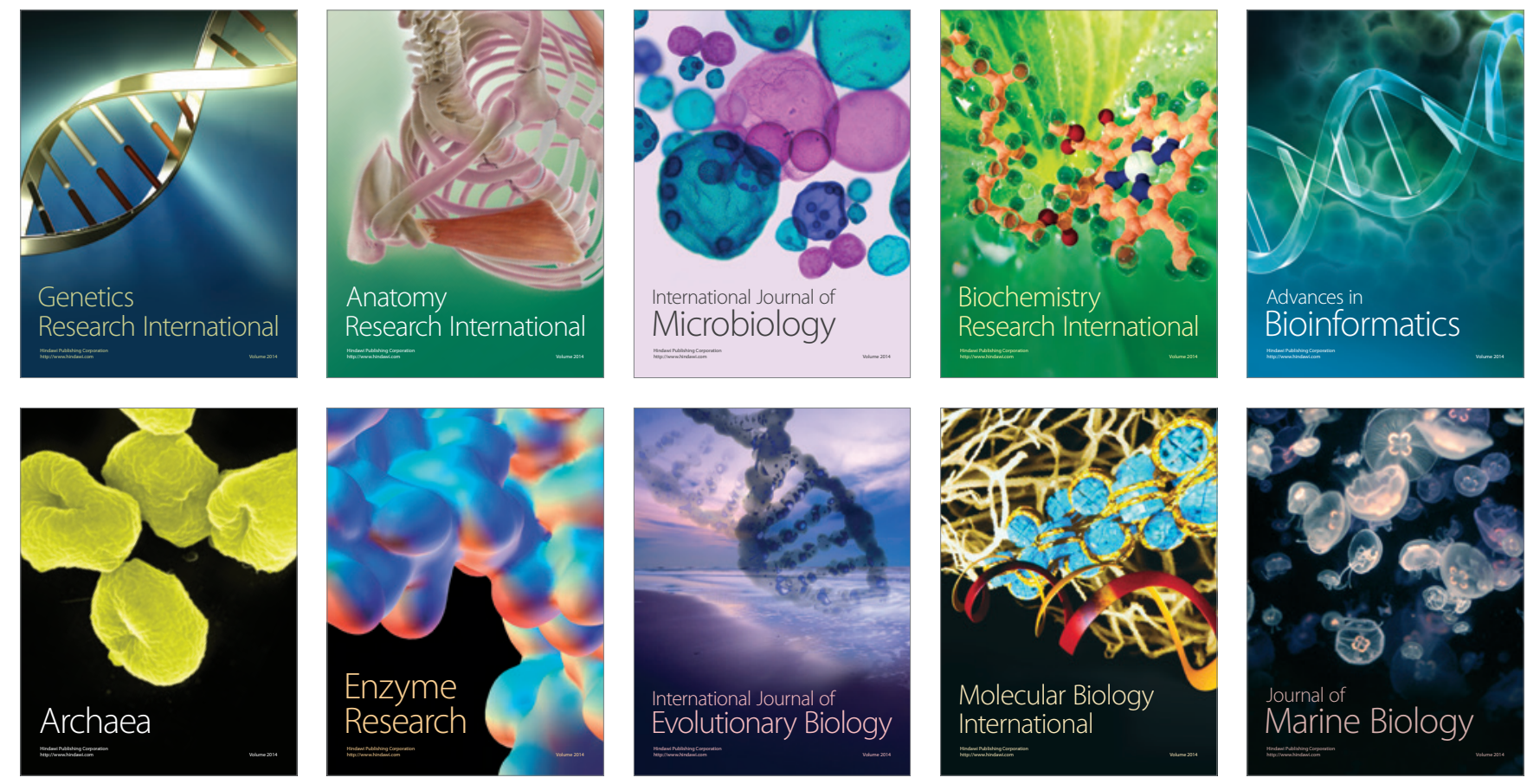